\title{
Using our Bodies Faithfully: Christian friendship and the life of worship
}

\begin{tabular}{|r|l|}
\hline Journal: & Journal of Disability \& Religion \\
\hline Manuscript ID: & WRDH-2015-0018 \\
\hline Manuscript Type: & Research Article \\
\hline Keywords: & $\begin{array}{l}\text { Dementia, Dependancy, Disability, Intellectual Disability, Inclusive } \\
\text { Congregations }\end{array}$ \\
\hline Abstract: & $\begin{array}{l}\text { The paper explores the significance of our bodies for an understanding of } \\
\text { what it means to be a member of the body of Christ and ultimately for } \\
\text { what it means to be human. Within the body of Christ, our bodies cease to } \\
\text { be our own. We discover that who we are is who we are "in Christ." As we } \\
\text { come to recognise that the essence of the body of Christ is its diversity and } \\
\text { unification in Christ, so we begin to see the importance of bodies that some } \\
\text { might consider to be different. The mark of the body of Christ is the } \\
\text { diversity of the bodies within it. Unity is created and held not through } \\
\text { equality but via diversity-in-Christ. Bodies matter. Through reflecting on } \\
\text { the experience of intellectual disability, dementia and mental health } \\
\text { problems, the paper lays out a theology of the liturgical body exploring } \\
\text { issues such as: the problem with mutuality in relationships with God, the } \\
\text { holiness of all human bodies and the critical significance of Christian } \\
\text { friendship for enabling the day-to-day life of worship. }\end{array}$ \\
\hline
\end{tabular}




\section{Using our Bodies Faithfully: Christian friendship and the life of worship}

Friendship is something that we do with our bodies ${ }^{1}$. It is a way of placing ourselves within creation wherein we adopt a posture of love and humility and seek to receive that which is offered to us by God and by others. Likewise worship is something that we do with our bodies. Worship occurs when we position our bodies in particular ways before the Creator and allow the Spirit to open our hearts to the transforming rhythm of God's intentions. Bodies matter.

Stephen Post describes Western people as hypercognitive ${ }^{2}$. We are a people who have a tendency to highlight and value intellect and cognition over such things as friendship, community and love. Western people prioritise the mind over the body; matter over spirit. As hypercognitive Western people we are constantly tempted to downgrade our bodies and upgrade our minds, assuming that thinking is the place where we gain true knowledge of the world, of one another and of God. But of course, thinking is not something that we do apart from our bodies. Thinking is a part of our bodily existance. Indeed the shape and form of our bodies shapes our thinking right down to the biological level. The very structure of our brains is moulded and formed not simply by our thinking, but by the whole of our experiences in the world. Unlike hair, teeth or eyes which function according to a preordained genetic plan, our brains develop as an outcome of our experiences ${ }^{3}$. As we encounter the world and one another within it, so our experiences are literally etched into our brains. Our neurones and synapses don't simply record our experiences. They are shaped and formed by our encounters with the world. In a quite literal sense our bodies are the shape of our experience of the world. As Pierre Bourdieu has aptly pointed out, we carry our cultures in our bodies ${ }^{4}$.

Bodies matter to Christians. At the heart of our faith is the broken body of Jesus. It is as we look upon the damaged body of Jesus on the cross that we come to realise that God is

\footnotetext{
${ }^{1}$ This paper was originally presented as the first of the Lochman Lectures held in Rhien, Switzerland in June 2015 The Lochman Lectures have emerged from an association between the university of Zurich, the University of Basel and a coalition of local churches based in Rheine and Basel in Switzerland. The intention of the lecture series is to bring together church and academy for a series of interdisciplinary scholarly conversations around a variety of key issues. (https://www.bildungkirche.ch/dokumente/Weitere-Bildungsanbieter/EvangelischesStudienhaus-Meierhof-Riehen/Lochman-Lectures-Flyer-def_f.pdf). Thank you to Dan and Martina Holder for putting this wonderful initiative together.

${ }^{2}$ Post, Stephen. (1995) The Moral Challenge of Alzheimer's Disease. Baltimore: Johns Hopkins Press. 1995.

${ }^{3}$ Doidge, Norman. (2008) The Brain That Changes Itself: Stories of Personal Triumph from the Frontiers of Brain Science. New York: Penguin.

${ }^{4}$ Bourdieu, Pierre (1990). The Logic of Practice. Boston: Polity Press.
} 
and remains embodied. It is in the wounded body of Jesus; amongst the blood and the incapacitation of the cross that our redemption is wrought. The surprise of the resurrection (apart from the obvious) is that Jesus' wounds remain a part of his resurrected body ${ }^{5}$. This indicates many things, but at a minimum, it suggests that standard perceptions of our post resurrection experience referring to a complete replacement of our current bodies or a movement from the physical to the immaterial, understood as diametrically opposed polarities, are flawed. The bodies that we have just now have something of eternal significance $^{6}$. Scripture does not tell us what that means or how that could be, only that that is so. Our bodies matter now, and for ever.

In this paper I will offer a perspective on the Christian body, on Christian worship and on Christ-like friendship. The perspective I will seek to offer will enable us to see the power and importance of Spirit-filled bodies for the tasks that Jesus has for us in-the-now and onwards in the eschaton. In developing a theology of the liturgical, spirit filled body I will engage with the experience of people whose bodies are considered to be different either because of damage, deterioration or genetic difference. In exploring difference within the Body of Christ we will be able to come to an understanding as to the radicalness of Christian friendship and the day-to-day power of faithful worship.

\section{The communal nature of Christian bodies}

The place that we need to begin our exploration into Christian bodies is with a deceptively simple observation: being a Christian is something that we do together. At first glance this may seem rather obvious. However, a deeper reflection reveals it to be a profound and crucial anthropological and Christological observation. When I say that "being a Christian is something that we do together," I don't mean that it is a series of tasks that we engage in as individuals who happen to be together within a particular geographical space. Rather, what I mean is that the very process of being a Christian and indeed of being human is communal right down to its core. Hypercognitive Western people feel that they are individuals. But such a feeling is illusory. We are deeply dependant creatures. At a basic human level, our dependency on one another is remarkably obvious if not always recognised. Despite our cultural mantra of "I think therefore I am;" a mode of self-perceptions that

\footnotetext{
${ }^{5}$ John 20:27: "Then he said to Thomas, "Put your finger here; see my hands. Reach out your hand and put it into my side. Stop doubting and believe."

${ }^{6}$ Wright, T. (2007) Surprised by Hope. London: SPCK.
} 
assumes autonomy, freedom and independence, we are inevitably dependant on one another at an individual, social and political level. The recent banking crisis has shown us that we are not only interdependent across national boundaries, but also that money - the thing that seems to drive all of humanity - does not in fact exist. If something as "obvious" as money can be found not to exist, then we might not be surprised to discover that "I" might not exist either, at least in the form that we normally think of our "I-ness". The African phrase "I am because we are," is in fact much closer to the truth ${ }^{7}$.

As Christians we discover another dimension to human inter-dependence. A dimension that challenges us to re-think the idea of personal identity. In 1 Corinthians 3: 16 the apostle Paul says:

"Don't you realize that all of you together ${ }^{8}$ are the temple of God and that the Spirit of God lives in you?"

"All of you together." The body of Christ is not intended as a metaphor. Richard Hays notes that Paul presses "beyond mere analogy to make an ontological equation of the church with Christ ${ }^{9}$." The body of Christ is a physical reality. It is something that creatures are called to participate in with their bodies. Within the Body of Christ there literally is no "I," only "we." Put slightly differently, within the Kingdom of God, the idea that " $P$ " am a discrete individual free to do whatever I want to do and to create myself in whatever way I want to, as long as I don't prevent others from doing the same, (the standard assumption about individuality in modernity), makes no sense. The suggestion that we are as deeply interconnected as this is inevitably dissonant with Western understandings and perceptions of self and what it means to be "me." The proposition that "I" can only be who I am when I recognise my interconnectedness with others and with Jesus raises questions. How can " $P$ " be "we." Of course "I" am "me!" And yet, that is exactly what the apostle Paul seems to indicate in his imagery of the church as the body of Christ. Those who follow Jesus and are baptised into his body are in Christ, not in a metaphorical sense, but in a real sense. We are who we are, not as individuals, but in Christ. We are not who we are when we stand alone. We are only who we are when we are together in Christ. As we engage with one another, so we engage with Jesus. We cannot truly be who we are without the other members who form the body of Jesus.

But we are not simply together. The body of Christ is not like a football match or a community gathering. We are together in Christ. Paul frequently uses "in Christ" language to

\footnotetext{
${ }^{7}$ Battle, Michael. (1997) Reconciliation: The Ubuntu Theology of Desmond Tutu. Cleveland: Pilgrim.

${ }^{8}$ Italics added.

${ }^{9}$ Hays, Richard. B. (1997). First Corinthians. Louisville, KY: John Knox Press. P. 213.
} 
express the true place of the churches' identity ${ }^{10}$. Again this is not a metaphor. Who we are can only be fully understood as we perceive ourselves in relation to Jesus. My history, my present experience and future hopes can only be understood as such things relate to and are seen in the light of Jesus. In Colossians 3:3 Paul informs us: "For you died, and your life is now hidden with Christ in God." Who we are is far from obvious. Before I became a Christian I thought I was doing pretty well! Then I met Jesus and discovered that I was a sinner in need of redemption. Who we are is often a mystery even to ourselves. It is only as we begin to discover who we are in Christ that we come to know who we really are.

For Paul, Christian bodies do not have any integral individuality ${ }^{11}$. Who we are is not who we may think we are, or who we choose to be, but who we are in Christ. Within the body of Christ Elizabeth Kent observes:

Our bodies should not be an autonomous project of self actualization. The radical disruption of Scripture calls us to understand the individual bodies as primarily part of the body of Christ. In sharp contrast to the secular culture which enshrines the autonomous individual body, and at variance with evangelicals who have appropriated that same concept, the challenge to view our own bodies through the lens of participation in the body of Christ subverts what we have been led to believe the body is for ${ }^{12}$.

As we are baptised into the Body, so we lose ownership of our own bodies and become one in Christ. It is not that our individual bodies cease to matter. They actually become more important as they find their true telos. Likewise it is not that we collapse into the Divine in a way that merges our individuality with God's radiance. We become more who we are as we learn to be in Christ. Think of it in this way. Is it possible for a Christian accurately to describe themselves without mentioning Jesus? Jesus is integral to who we are and what we know about ourselves. As we lose ownership of our own bodies, and as we cease trying to create our own stories, so we begin to discover what the bodies that we inhabit are actually for. Our bodies are in Jesus and for Jesus. Beginning to think of ourselves in such interconnected ways opens up some new possibilities and some deep challenges. Paul rips away the veil of independence and individuality and challenges us to think corporately and Christologically about who we are and what we should be doing with our bodies.

\footnotetext{
${ }^{10} 1$ Corinthians $15: 12-24$

${ }^{11}$ For a fuller development of this suggestion see Dale. B. Martin (1995) The Corinthian Body. Connecticut: Yale University Press.

${ }^{12}$ Elizabeth Kent. 'Embodied evangelicalism: The body of Christ and the Christian body.' In Tom Greggs (ed) (2010) New Perspectives for Evangelical Theology: Engaging with God, Scripture and the world. London: Routledge. P. 116
} 
Unity in diversity: Places of belonging

Within the body of Jesus there is a deep and necessary diversity. Within Christ's body people are not treated equally. Equality is an elusive and difficult concept. If we were, for example, to treat people with advanced dementia equally - in the way we treat people who do not share that experience - then we would create a situation of deep injustice and oddly, profound inequality. Equality is a political term that requires theological nuance. Within Jesus's body diversity is the new norm and respect for diversity is the assumed way of being in the world. Human beings in all of their diversity find their unity in Christ. As people are baptised into the body of Christ, so they enter into a space of deep belonging. To belong one needs to be perceived as invaluable and absolutely necessary for the functioning of the community. People need to miss you when you are not there. The body of Christ is a place of belonging $^{13}$. The body cannot be the body without the hand; it cannot be complete without the little toe! If the left arm tries to be the right arm the body will suffer until the left arm finds its vocation and settles into its lefthandedness. The diversity of Jesus' body is inevitable and necessary. But such diversity is not held together by equality, but by deep belonging.

\section{God with us}

We do however have to be careful and clear as to the nature of the relationality within the body of Christ. It is not a side issue that in the body we become who we are "in Christ." It is as Jesus comes to us and chooses to relate to us that we are drawn into his body. The interconnectivity between God and human beings should not be mistaken for a relationship of mutuality. David Kelsey notes that

What Christians claim about humankind that nobody else does is that the triune God relates to humankind, and to all else, to create it, to draw it to eschatological consummation, and, when it is estranged, to reconcile it $^{14}$.

Kelsey's point is that the key issue for Christians is not that they relate to God, but that God relates to them. The relationality within the body of Christ is not equal. Scripture consistently tells a story of God relating to that which is not God; to a "reality other than God ${ }^{15}$." The relationship between God and creatures is not static and is not like other relationships that human beings engage in. This inequality between human and Divine relationships is very

\footnotetext{
13 J. Swinton. (2012) "From Inclusion to Belonging: A Practical Theology of Community, Disability and Humanness", Journal of Religion, Disability \& Health, vol. 16, pp. 172-190.

${ }^{14}$ David. H. Kelsey. 'Personal Bodies: A theological anthropological proposal.' In Lints, Richard., Horton, Michael. S., and Talbot, Mark.R (2006) Personal Identity in Theological Perspective. Grand Rapids: Eerdmans. P. 142

${ }^{15}$ Kelsey, Personal Bodies: P. 142.
} 
important. Not only is there a difference between God relating to humans and humans relating to God, Kelsey also points out that:

The Christian claim is that humankind's relating to God is generally not congruent with, nor an appropriate response to, God's relating to humankind. That is, human relating to God is generally sinful. To declare abstractly that human creatures have the property of "God-relatedness" simply obscures the distinction between God relating to us and our relating to God. What makes Christian anthropology theological is that it is ruled by claims about God relating to us. More exactly, it is ruled by claims about the triune God relating to us. Such anthropology must be theocentric. Only in and from that context should we derive claims about our relating to God. Speaking of "God relating" rather than about "the God relation" brings that out ${ }^{16}$.

Kelsey's point is important for two reasons, one theological and one practical. The theological point is vital. To suggest that human beings have some kind of inherent property that constitutes their 'God-relatedness' is an anthropological statement, not a theological statement: a statement about human beings rather than a statement about God. More, it is a statement about human beings that misses the point of the biblical narrative that indicates that it is 'God's relating' that should be perceived as the primary theological dynamic. Humans can relate to God, but only within the context of God's primary relational dynamic and an acknowledgement of human sinfulness.

The practical dimension to Kelsey's observations is crucial for current purposes. If human understandings of what it means to relate to God provide the primary relational dynamic within which human and Divine interactions are presumed to occur, then our understandings of what it means to relate to God will be bound up in human expectations and human sinfulness. In other words, if our perspective on what it means to relate to God comes from a human point of view, then it will be bound by what humans think relating to God means. But, if our understanding of what it means to relate to God comes from a Divine point of view, then a whole new range of options emerge. Not noticing this tension between God relating to us and us relating to God sits at the heart of controversies over whether or not people with profound intellectual disabilities or people with advanced dementia, can relate to God, or should be allowed to participate in the rituals and practices of faith. The presumption is that we need to know something or do something in order to relate to God. Relating becomes a human enterprise. However, framing the issue in the way Kelsey does, leaves conceptual room for "stressing that "God actively relating" is said in several senses, not one ${ }^{17}$. Put slightly differently, the love that binds and holds the body of Christ; the active

\footnotetext{
${ }^{16}$ Kelsey, Personal Bodies: P. 143

${ }^{17}$ Kelsey, Personal Bodies: P. 143
} 
relating love of God, is not univocal; it doesn't have a single voice. Because the initiative is always God's and because God relational activities, are multivocal (have many voices and cadences), all of the members of God's body should always be able to participate. God relates to all members of the body in ways that are simultaneously diverse and unified. The body of Christ is a place of participation, difference and acceptance.

\section{No room at God's table}

An example will help to make the point. A few years ago a colleague of mine who has a daughter with Down's syndrome attended a church in the north of Scotland. His daughter was a very active member of the church and engaged enthusiastically in all dimensions of worship in their own congregation. The day that they attended worship was the time of communion, of Eucharist. When the cup went round the congregation it came to my friend's daughter, her name is Janet. She was about to take the sacrament when suddenly the minister in a very loud voice shouted "don't let that woman take the sacrament! She will defile it." Now, it is difficult to gauge precisely what the minister's problem was apart from bad manners and rudeness. Presumably he had in mind Paul's statement in 1 Corinthians 11: 29: "For those who eat and drink without discerning the body of Christ eat and drink judgment on themselves." A generous reading of the situation would be that he was trying to protect her from engaging in a dangerous spiritual practice. It would be interesting to know if he treated all of his visitors like this, or whether his "care" and "concern," was reserved for those who looked different from others in the gathering. A less generous reading of the situation would be that he assumed that Janet was unable to understand the sacrament and by implication understand and relate to God in standard ways. This is not the place to get into the complexities of sacramental participation and exclusion from God's table ${ }^{18}$. Suffice to point out that if my less generous reading is correct, the minister's thinking and response was carried out at the level of anthropology, not theology. The assumption being that Jane had to know something before she could relate to God. However, at a theological level, there is no reason why a God who relates in the midst of human diversity cannot relate to Janet with all of her differences. Relatedness within the body of Christ is diverse, loving, accepting and above all gifted. All of the members may not understand or accept the gift in the same way, but then again God does not give the gift in the same way to every member. If we begin to

\footnotetext{
18 For a very helpful exploration of the Eucharist, see Weljker, Michael(200) What Happens in Holy Communion? Grand Rapids: Eerdmans. Also: Michael, Ralph. (2010) Eucharist: A guide for the perplexed. Edinburgh: $T \&$ \& Clark.
} 
think theologically rather than anthropologically about the body of Christ things look different.

\section{The soulfulness of the body}

God's offer of relationship is thus seen to be a gift that cannot be emulated by human beings. It can however be lived into, as we live within the body of Jesus. As we receive God's gift, so we learn what it means to live into God's Grace. God's relating is therefore a transformative gift that moves people closer to Jesus and thus closer to the image of God whom Paul informs us is Jesus ${ }^{19}$. We will see in a moment that the body of Christ is vital for an understanding of the context for Christian friendship and faithful worship. But before we do so, we need to spend a little time reflecting on the nature of the bodies that comprise the body of Christ. Human bodies are holy places. In Genesis 2:7 we find a description of the origins of human beings:

And the LORD God formed man [of] the dust of the ground, and breathed into his nostrils the breath of life; and man became a living soul. (KJV)

God breathes God's breath into human beings and they move from being inanimate dust to living beings. St. Augustine describes human beings as terra animata, "animated earth ${ }^{20}$." Humans are thus seen to be created from matter, but inspired/given breath/brought into living existence by the very breath of $\operatorname{God}^{21}$. If that is the case then something very powerful begins to emerge. We are our bodies as we are our souls. As earth animated by the breath of God, human beings are seen to be, as Wendell Berry has put it: "holy creatures living among other holy creatures in a world that is holy ${ }^{22}$." Put slightly differently, Every-Body is holy. That is not to suggest that humans are holy in and of themselves. They are holy because the breath of God who is Holy resides within them and sustains them. This of course has an immediate implication. Attending to God's creatures is in fact a mode of attending to God. As we minister to one another in love and friendship so we also minister to God. Friendship is worship; community is soul work.

\footnotetext{
${ }^{19}$ Colossians 1:15-17: "The Son is the image of the invisible God, the firstborn over all creation. For in him all things were created: things in heaven and on earth, visible and invisible, whether thrones or powers or rulers or authorities; all things have been created through him and for him. He is before all things, and in him all things hold together."

${ }^{20}$ Gilbert Meilaender, "Terra es Animata on having a life", The Hastings Center Report, Vol. 23, No. 4 (Jul. Aug., 1993), pp. 25-32 ), p. 25. St. Augustine, De civitate Dei, trans. Henry Bettenson (New York: Penguin Books, 1972), Section 20.20. Augustine's City of God.

${ }^{21}$ For a further development of this way of thinking see Swinton, John. (2012) Dementia: Living in the Memories of God Grand Rapids: Eerdmans. (especially chapter 7)

${ }^{22}$ Berry, Wendell. (2002)The Art of the Commonplace: The Agrarian Essays of Wendell Berry. Berkeley: Counterpoint Press. P. 308
} 
That is not to suggest that we should look beyond or around each other in a search for God. This is precisely what Luther felt that people were doing with regard to the cross of Jesus. His theology of the cross forces people to look at the cross, to look at Jesus ${ }^{23}$. We don't look over or around the person before us, in an impersonal search for God. As we look properly at one another so we come to see God. God is in the midst of all that we do and all that we are. God is a gentle, inspiring presence that creates us, holds us, and invites us to see the holiness of others. Each human encounter is an occasion for worship; an opportunity to place our bodies in particular ways before God and for the other. Worship in this sense is a everyday celebration of human bodies. It is a repositioning of the brokenness of humanity. Worship provides a space within which the body of Christ can take shape and form as it seeks to respond faithfully to the calling of Jesus. Human encounter is a celebration of the body and a meeting of souls. Within this context every-body has a place. Whilst there may be powerful liturgical moments where we formally engage in the rituals and practices of our faith within the geographical boundaries of our churches, worship conceived in the day-to-dayness of human encounter opens up a space for a liturgy of the everyday. Such a liturgy draws attention to the sacrament of the present moment ${ }^{24}$; a way of looking at and living in the world wherein we recognise that each moment is a gift and that the movements of our bodies in the world and the cadence of our spirits, provide the context for the liturgy of our lives.

\section{Worshipping with our bodies}

If we take this way of being in the world into our encounters with people who have advanced dementia, the power of the liturgical body emerges in surprising ways. For many years I worked alongside of people living with advanced dementia. There are many tales that I could tell, but here I want us to concentrate on worship. One of the startling things about spending time with people who have advanced dementia is the ways in which many people respond to worship. People who have very little response during the week will often spring into life when they hear the Lord's prayer, a hymn or are invited to participate in the sacraments. Some would argue that this is nothing more than well engrained cognitive memory. It may well be that that is an aspect of the story. But there is more. People's movements in the context of worship are a manifestation of memory: the memory of their bodies. There is a burgeoning literature that makes the case that we not only recall our

\footnotetext{
23 Forde, Gerhard O. (1997) On being a Theologian of the Cross, Reflections on Luther's Heidelberg Disputation, 1518 Grand Rapids: Wm. B. Eerdmans Publishing Co.

${ }^{24}$ de Caussade, Jean-Pierre. (1989)The Sacrament of the Present Moment. San Francisco: Harper Collins.
} 
memories; bringing things from the past into the present with a view to planning the future. We also embody our memories ${ }^{25}$. Our memories are not simply brought from the past into the present; they are actually embodied and worked out in the present through our bodily practices. Many of the folks with whom I worked were Christians. Many of them had forgotten Jesus, at least at a cognitive level (or at least they seemed to have. Who knows?). This raises an interesting question: What does it mean to know and to love Jesus when you have forgotten who he is? But, they remembered Jesus, in their bodies. Over time these people had been shaped, formed and educated in the practices of the church. They were not simply "I" people, they had become "we" people in their very essence. Their bodies contained and acted out the body of Christ in worship. As I have written elsewhere, over time:

their bodies had been shaped and formed by faithfully practising the memory of Jesus over many years. They could not recall who Jesus was, but their love for Jesus and their memory of him; their faithfulness over time was made manifest in their bodies and was obvious if people had eyes to see. Viewed in this way, their frail movements, the taking of the bread and the wine, their fragile embrace, the apparently unknowing sharing in the words of the ritual are reflective not of loss but of enduring love. They represent the habits of a lifetime inscribed by Jesus on the bodies of those who love and, in an odd way, remember Jesus "in the now" in ways that do not require recall or cognition. They know and remember Jesus in their bodies ${ }^{26}$.

In order to notice such beautiful things, we need to be able to look at our bodies properly. When we learn to see the holiness of even the most broken body, we act differently; we function generously and gently. We become people who can be trusted with the welfare of others. We become not just servants to the disabled; we become friends: heart to heart, soul to soul. Servants have a sense of "I"ness (distance); friends are bound in "We"ness (intimacy).

\section{Christ like friendship}

And that movement from servants who seek to offer care, to friends who seek to offer love, takes me to the final part of my paper. The designation that scripture uses to name the faithful bodies that make up the body of Christ is friends. When in John 15:15 Jesus says to his disciples "I no longer call you servants, now I call you friends" the disciples are given a

\footnotetext{
${ }^{25}$ Koch, C. Sabine., Fuchs, Thomas., Summa, Michela and Müller, Cornelia (eds). (2012) Body Memory, Metaphor and Movement. John Benjamins Publishing Company.

${ }^{26}$ Swinton, John. (2014) 'What the Body Remembers: Theological: Reflections on Dementia.' Journal of Religion, Spirituality \& Aging, 26:2-3, 160-172. P. 168.
} 
radically new identity. Now they are not simply followers of Jesus, they are friends of God. But what might such friendship look like.

A number of years ago I wrote a book called Resurrecting the Person: Friendship and the care of people with severe mental health problems ${ }^{27}$. It was an extended reflection on the experiences of people living with schizophrenia and the role of Christian friendship in their spiritual recovery. In concluding this lecture I want to reprise some of the argument of that book in the service of putting some flesh to the type of relationship I have been pushing for thus far.

One of the strange things about Western friendships is that they are pretty exclusive. If we look at our social circles, many if not most of our friends tend to be remarkably similar to ourselves. We share certain beliefs, do things that we like together, share interests and so forth. The basic approach is based on an intuitive Aristotelian principle of like-attracts-like ${ }^{28}$. We relate to one another more or less in the same way as we do our economics, that is, according to a principle of social exchange: You give me an adequate amount of social and emotional goods and I will do the same. As long as we retain the equilibrium of the exchange I will remain your friend. But if you can't or won't satisfy me or can't afford to give me what I need, then I will find friends elsewhere. We assume that friendship is a choice based on utility. Such a structure makes it very difficult for us to imagine what it might look like to become friends with someone who seems in many ways very different from who we are (or whom we perceive ourselves to be). Put slightly differently, there is a reason why many people do not want to spend time with people who have visible or invisible disabilities: we have been taught not to. Many of us simply don't have the relational sensitivities that would enable us to deal creatively with relational difference. I remember one young man with whom I worked who had enduring schizophrenia. He had just been successfully hooked up with a befriending scheme. It was working quite well and he said to me: "you know John, I am 24 years old and this is the first time that I have had a friend who has not been paid to be my friend." That strikes me as quite profound. Deep loneliness marks the experience of many people with mental health issues. One has to wonder where the community of Jesus' friends is in the midst of such loneliness and isolation.

\footnotetext{
${ }^{27}$ Swinton, John. (2000) Resurrecting the Person: Friendship and the care of people with severe mental health problems. Abingdon Press, Nashville.

${ }^{28}$ For Aristotle, friendship could only occur between equals, that is, two good people serving to actualise the virtue of goodness within their friendship relationship. In this understanding the tendency is to work on a principle of likeness. (Aristotle. (1987) The Nichomachean Ethics, trans. J. E. C. Welldon. New York: Promethian Books.
} 
The friendships of Jesus.

However, the friendships of Jesus run in a different direction. The principle of the incarnation is that God who is radically unlike human beings, takes the form of human beings and offers them friendship. Jesus who is God offers friendship to the disciples. Once again we see the importance of Kelsey's point. We do not choose to be friends of Jesus; Jesus chooses us as friends:

You are my friends if you do what I command. I no longer call you servants, because a servant does not know his master's business. Instead, I have called you friends, for everything that I learned from my Father I have made known to you. You did not choose me, but I chose you and appointed you so that you might go and bear fruitfruit that will last - and so that whatever you ask in my name the Father will give you. (John 15: 14-16).

One might counter with the question "but does not Jesus put in a caveat! "if you do what I command." Does that then mean that God wants something from us in return for his friendship? Is God's offer of relationship really a gift for all? At one level it does look as if Jesus is bounding his friendship with a command to do something in return. And in one sense that is so. But things become clearer when we learn what it is that Jesus wants us to do. He wants us to love one another: "My command is this: Love each other as I have loved you (John 15: 12). To be human is to be loved. God wants to teach us how to be human. The command is not a proviso. It is part of the gift. Before we were anything, we were loved ${ }^{29}$. We were brought into the world by love and for love ${ }^{30}$. Jesus' command to love is not so much a caveat on friendship, but more an aspect of the gift of humanness. Christ-like friendship is a mode of re-humanisation.

Love is patient, love is kind. It does not envy, it does not boast, it is not proud. It does not dishonour others, it is not self-seeking, it is not easily angered, it keeps no record of wrongs. Love does not delight in evil but rejoices with the truth. It always protects, always trusts, always hopes, always perseveres (1 Corinthians 13: 4-7).

Importantly, love is not a concept; it is a practice that has a dynamic of giving and receiving. This is an important point. One might ask, "if the command is to love and if someone is so damaged that they cannot give love, at least in the ways that Paul suggests, does this mean that friendship is inaccessible?" Again the answer is no. Love is a dynamic concept (a concept that works in different directions) that finds its power and potency simultaneously

\footnotetext{
29 Psalm 139:15-16: "My frame was not hidden from you when I was made in the secret place, when I was woven together in the depths of the earth. Your eyes saw my unformed body; all the days ordained for me were written in your book before one of them came to be.

${ }^{30}$ John 3:16: "For God so loved the world that he gave his one and only Son, that whoever believes in him shall not perish but have eternal life."
} 
and equally in both giving and receiving. Partaking in the life of love is not something that we do alone and it is not something that pertains only to the giving of gifts; it is something we participate in, wherein both giving and receiving are equally vital aspects of love. So, when we receive the gift of friendship, to use Hans Reinders expression ${ }^{31}$, we participate in the fulfilment of Jesus' command to love, not simply by doing but also by receiving. The act of receiving love is dynamically equivalent to the acts of giving love. The love and friendship that Jesus offers is therefore equally as open to those who cannot cognate and receive the offer as it is to those who can actively participate. That is one reason why "love never fails ${ }^{32}$."

\section{Sitting with the marginalised}

The point I want to develop here is the way in which Jesus' relational dynamic grounded itself in a particular form of friendship. Jesus sat with those folks that society did not want to sit with. He sat with the marginalised, the rejected, the unfriended to use a Facebook term! So the principle that we see in the friendships of Jesus is a principle-ofGrace' that refuses to be bound by a principle-of-likeness. Jesus's friendships model the kind of embodied being together that we have been reflecting on thus far. Such friendship is the very stuff of the body of Christ.

\section{Sitting with the marginalised?}

However, there is one final dimension of Jesus's friendships that we must take a little time to reflect upon. Often we think of Jesus' ministry as being with and for the marginalised. Such a perception, I would suggest, is a mistake. Think of it in this way. Jesus who is God enters into relationships of friendship with those whom society has marginalised. But in doing so Jesus shifts the margins. The religious community continues to carry out the rituals and practices that they think bring them closer to God. But God is somewhere else: with those whom they have marginalised: with Jesus. So it turns out that it is the religious folks that are marginalised because they could not understand the significance of those whom they chose to reject. My fear is that precisely the same thing happens today in relation to issues of disability and difference. When churches fail to see the significance of working to include those with different needs, different bodies and different experiences, they find themselves

\footnotetext{
${ }^{31}$ Hans Reinders. (2008) Receiving the Gift of Friendship: Profound Disability, Theological, Anthropology, and Ethics Grand Rapids: Eerdmans.

321 Corinthians 13:8.
} 
14

marginalised from Jesus. Working to create communities of belonging which truly represent Jesus' body is not simply a good and proper thing to do. It is vital for the future of the church. If the church truly wants to be the body of Jesus, perhaps it needs to recognise its own alienation and embrace the fullness of Jesus' body in ways that are hospitable, faithful and friendly. On that day, the body will be whole. 